\title{
Target cell-restricted apoptosis induction by 528scFv-TRAIL fusion protein specific for human EGFR and expressed in Escherichia coli
}

\author{
ADEL BADRAN $^{1}$, RYUTARO ASANO ${ }^{1}$, MAKOTO NAKAYAMA ${ }^{1}$, YASUHIRO WATANABE ${ }^{2}$, \\ TAKESHI NAKANISHI ${ }^{1}$, MITSUO UMETSU ${ }^{1}$, HIROKI HAYASHI ${ }^{2}$, \\ YU KATAYOSE $^{2}$, MICHIAKI UNNO ${ }^{2}$ and IZUMI KUMAGAI ${ }^{1}$ \\ ${ }^{1}$ Department of Biomolecular Engineering, Graduate School of Engineering, Tohoku University, \\ Sendai 980-8579; ${ }^{2}$ Division of Gastroenterological Surgery, Department of Surgery, \\ Graduate School of Medicine, Tohoku University, Sendai 980-8574, Japan
}

Received October 19, 2009; Accepted December 3, 2009

DOI: 10.3892/ijo_00000606

\begin{abstract}
We report the preparation and functional characterization of an Escherichia coli-expressed recombinant fusion protein, 528scFv-TRAIL, specific for the human epidermal growth factor receptor (EGFR) and empowered by the tumor necrosis factor-related apoptosis-inducing ligand (TRAIL). The $528 \mathrm{scFv}$-TRAIL, expressed as insoluble inclusion bodies in E. coli, was solubilized and then refolded by using a modified stepwise dialysis method. Treatment with $528 \mathrm{scFv}$-TRAIL resulted in the specific binding to the cell surface of EGFRpositive cells with concomitant deployment of the TRAIL moiety to DR-5 receptor in a manner comparable to a commercially available form of recombinant TRAIL (cTRAIL). $528 \mathrm{scFV}$-TRAIL, prepared by either of three refolding processes described herein, showed potent cytotoxic activity against EGFR-positive TFK-1 cell line and was superior to its parental $528 \mathrm{scFv}$; a recombinant variable fragment with single specificity against human EGFR. Narrow variations in the cytotoxic potential of 528scFv-TRAIL were ascribed to manipulation of redox conditions during the refolding process. Together, our findings point to the potential value of $528 \mathrm{scFv}$-TRAIL for treatment of EGFR-expressing cancers. Furthermore, preparation of 528scFv-TRAIL from insoluble aggregates in a prokaryotic cell based expression system by means of in vitro refolding introduces a feasible cost-benefit, time-efficient approach for industrial-scale production.
\end{abstract}

\section{Introduction}

Antibodies (Abs) are some of the most powerful tools in therapy and diagnostics and are currently one of the fastest

Correspondence to: Dr Izumi Kumagai, Aoba 6-6-11-606, Aramaki, Aoba-ku, Sendai 980-8579, Japan

E-mail: kmiz@kuma.che.tohoku.ac.jp

Key words: fusion protein, scFv, E. coli, EGFR, TRAIL, apoptosis growing classes of therapeutic molecules. Recombinant antibody $(\mathrm{rAb})$ fragments are becoming popular therapeutic alternatives to full length monoclonal Abs since they are smaller, possess different properties that are advantageous in certain medical applications, can be produced more economically and are easily amendable to genetic manipulation. Single-chain variable fragment (scFv) Abs are one of the most versatile $\mathrm{rAb}$ formats as they have been engineered into larger, multivalent, bi-specific and conjugated forms for many clinical applications (1).

Induction of apoptosis has been established as an important approach in the development of novel anti-cancer therapeutics. Cells can undergo apoptosis via two different pathways: the intrinsic and extrinsic. The intrinsic pathway is preferentially triggered by intracellular proteins such as p53 in response to a wide range of damaging influences, for example radiation and chemotherapy. Intrinsically triggered apoptosis is mainly regulated by proteins of the Bcl-2 family that control the release of pro-apoptotic factors from the mitochondrial intermembrane space. In contrast, the extrinsic pathway is triggered by activation of death receptors which belong to the tumor necrosis factor (TNF) receptor superfamily. These cell surface receptors are activated when crosslinked by their ligands. Ligand-induced death receptor crosslinking then initiates a downstream intracellular signal transduction cascade culminating in apoptosis.

Within the TNF superfamily of cytokines, the TNF-related apoptosis-inducing ligand (TRAIL) has emerged as the most promising for death receptor targeted cancer therapy due to its remarkable feature of selectively inducing apoptosis in tumors in vivo without causing toxicity to normal cells (2). TRAIL was first identified on the basis of its high sequence homology to CD95L and TNF $(3,4)$. Among all death-inducing ligands, the TRAIL pathway is the most complex with five different TRAIL receptors being reported. However, only two of them, TRAIL-R1 (DR4) and TRAIL-R2 (DR5), are able to execute a full-fledged apoptotic cell death (5-7).

TRAIL-R1 and -R2 harbor a death domain (DD) in their intracellular portion, a six-seven $\alpha$-helices motif which can 
bind to other DDs via homotypic interactions (8). TRAIL binds to TRAIL-R1 or -R2 which leads to receptor homo- or heteromerical trimerisation (9) and subsequent recruitment of Fas associated death domain protein (FADD/Mort1) to their intracellular DDs. FADD acts as adaptor protein by itself having both a DD and a death effector domain (DED) which enables caspase- 8 and -10 as well as cellular FLICE inhibitory protein (cFLIP) to bind via their respective DDs. The resulting multiprotein complex is referred to as the DISC (10-12). The formation of the TRAIL DISC promotes conversion of pro-caspases into their active forms which can then activate downstream caspases. Following their activation at the DISC, caspase- 8 and -10 are cleaved in an autocatalytic process, generating large and small subunits. These form active hetero-tetramers which activate downstream effector caspases, e.g., caspase-3 and -7 (13).

EGFR is a well-established target antigen featuring oncogenic mutations, overexpression and aberrant signaling in various human carcinomas such as colorectal, bile duct, breast and lung carcinomas (14-18). Signaling through EGFR is considered to regulate tumor cell functions, such as cell-cycle progression, inhibition of apoptosis, angiogenesis, tumor cell motility, adhesion, and invasion (19-25).

Here we introduce an efficient cost-benefit strategy based on an E. coli expression system and in vitro refolding for the production of a recombinant fusion protein, $528 \mathrm{scFv}$-TRAIL, that combines EGFR-signaling inhibition with TRAILmediated target cell-restricted apoptosis induction.

\section{Materials and methods}

Construction and cloning of 528scFv-TRAIL. 528scFv-TRAIL was constructed in the T7 promoter-based pUT plasmid encoding an $\mathrm{N}$-terminal His tag upstream of the cloning sites. The $528 \mathrm{mAb}$ is a murine IgG2a directed to the human EGFR antigen (26). The V-region genes of 528 hybridoma cells were cloned by reverse transcription (RT)-PCR as described previously (27). The heavy chain (VH) and light chain (VL) genes were then amplified by PCR using the primer mix previously reported by Krebber et al (28). The VH and VL domains were genetically linked via a flexible peptide linker $(\mathrm{Gly} 4 \mathrm{Ser})_{3}$ in the orientation $\mathrm{VH}-(\mathrm{Gly} 4 \mathrm{Ser})_{3}$ VL. The antibody variable fragment $528 \mathrm{scFv}$, encoding VH(Gly4Ser) ${ }_{3}$-VL, was directionally inserted using restriction enzymes $\mathrm{NcoI}$ and XhoI. A second (Gly4Ser) ${ }_{3}$ linker and the XhoI restriction site were added to the carboxyl terminus of VH-(Gly4Ser) $)_{3}$-VL fragment via PCR amplification. A PCR-truncated DNA fragment encoding amino acids 114-281 of the extracellular domain of human TRAIL (29) was then cloned in frame using restriction enzymes XhoI and BamHI. The $\mathrm{N}$ terminus of the TRAIL fragment was thus linked to $528 \mathrm{scFv}$ via the second $(\mathrm{Gly} 4 \mathrm{Ser})_{3}$ linker, yielding plasmid pUT-528scFv-TRAIL (Fig. 1).

Expression of 528scFv-TRAIL in E-coli. 528scFv-TRAIL fusion protein was prepared from inclusion bodies expressed in $E$. coli as described previously $(27,31)$. In brief, $E$. coli strain BL21 (DE3) harboring the bacterial expression vector pUT-528scFv-TRAIL was grown at $28^{\circ} \mathrm{C}$ in Luria-Bertani broth. In order to induce protein production, $1 \mathrm{mM}$ isopropyl- 1-thio- $\beta$-D-galactopyranoside (IPTG) was added to the culture and the cells were grown overnight. Cells were harvested by centrifugation $(2000 \mathrm{x} \mathrm{g}, 35 \mathrm{~min})$, resuspended in $10 \mathrm{ml}$ phosphate-buffered saline (PBS), ultrasonicated at $150 \mathrm{~W}$ for $15 \mathrm{~min}$ and centrifuged at $4500 \mathrm{x} \mathrm{g}$ for $20 \mathrm{~min}$. The precipitating intracellular insoluble fraction was separated and the pellet was solubilized overnight at $4^{\circ} \mathrm{C}$ in $10 \mathrm{ml}$ of $6 \mathrm{M}$ guanidinium hydrochloride in $\mathrm{PBS}$ ( $\mathrm{Gu}-\mathrm{HCl} / \mathrm{PBS})$. Solubilized proteins were purified through a $2 \mathrm{ml}$ Talon Metal Affinity Resin column (Clontech, Palo Alto, CA, USA), followed by elution with $6 \mathrm{M} \mathrm{Gu}-\mathrm{HCl} / \mathrm{PBS}$ containing 50 , 150 and $500 \mathrm{mM}$ imidazole respectively.

Refolding of $528 s c F v$-TRAIL. We applied either of three refolding processes to prepare $528 \mathrm{scFV}$-TRAIL from the above purified sample. In refolding process I, solubilized $528 \mathrm{scFv}$-TRAIL was diluted to $7.5 \mu \mathrm{M}$ with $6 \mathrm{M} \mathrm{Gu}-\mathrm{HCl} / \mathrm{PBS}$, the redox reagent $\beta-\mathrm{ME}$ was then added at a final concentration of $375 \mu \mathrm{M}$. The denatured 528scFv-TRAIL (5 ml) underwent step-wise dialysis into PBS through solutions of $6,3,2$ and $1 \mathrm{M} \mathrm{Gu}-\mathrm{HCl} / \mathrm{PBS}$ with buffer exchange every $6 \mathrm{~h}$, thereafter through solutions of 0.5 and $0.0 \mathrm{M} \mathrm{Gu}-\mathrm{HCl} / \mathrm{PBS}$ with buffer exchange at 12-h interval. At the dialysis steps of 1 and $0.5 \mathrm{M} \mathrm{Gu}-\mathrm{HCl} / \mathrm{PBS}$ we added each of $400 \mathrm{mM}$ L-arginine and $375 \mu \mathrm{M}$ oxidized glutathione (30), Fig. 2 shows a schematic depiction of the refolding steps. In process II, PBS was replaced by $50 \mathrm{mM}$ Tris- $\mathrm{HCl}$ containing $200 \mathrm{mM}$ $\mathrm{NaCl}$ and $1 \mathrm{mM}$ EDTA. Step-wise dialysis was then carried out essentially as described in process I. In process III, removal of guanidine was carried out through one-step dialysis into $0.0 \mathrm{M} \mathrm{Gu}-\mathrm{HCl} / \mathrm{PBS}$ containing $400 \mathrm{mM} \mathrm{L}$-arginine over a period of $12 \mathrm{~h}$. L-arginine was then removed by dialysis against PBS for another $12 \mathrm{~h}$. In process III, neither pretreatment with $\beta-\mathrm{ME}$ nor oxidized glutathione conditioning was performed. In all three refolding processes, the external buffer solution was continually adjusted to $\mathrm{pH} 8.0$ at $4{ }^{\circ} \mathrm{C}$.

Gel filtration chromatography. Gel filtration analysis with a Hiload Superdex 200-pg column (10/300; GE Healthcare Bio-Science Corp., Piscatway, NJ, USA) was used to evaluate the molecular mass and structure of the refolded fusion protein. The column was pre-equilibrated with PBS, and then $250 \mu 1$ of the refolded recombinant protein was applied to the column at a flow rate of $0.5 \mathrm{ml} / \mathrm{min}$.

Flow cytometric analyses. EGFR and DR5 specific binding by $528 \mathrm{scFv}$-TRAIL was assessed by flow cytometry using the EGFR-positive, DR5-positive tumor cell line TFK-1 (human bile duct carcinoma) and the EGFR-negative, DR5positive tumor cell line Jurkat (human T cell leukemia). In short, $1 \times 10^{6}$ cells were first incubated on ice with equal molar concentrations of either 528scFv-TRAIL or cTRAIL (commercial recombinant TRAIL: TRAIL extracellular domain amino acids 114-281 with N-terminus His tag, Funakoshi, Japan). After being washed with PBS $+0.1 \% \mathrm{NaN}_{3}$, cells were incubated with anti-TRAIL rabbit polyclonal IgG (CosmoBio, Japan) and then washed and incubated with FITC-conjugated anti-rabbit IgG (Santa Cruz, USA). Incubations were carried out for $30 \mathrm{~min}$ at $0^{\circ} \mathrm{C}$. The fluorescence-activated cells were analyzed by flow cytometry (FACSCalibur, BD Biosciences). 


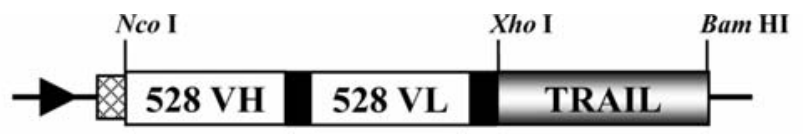

pUT-528scFv-TRAIL

\section{T7 promoter $\otimes$ His-tag $\quad$ Peptide linker (GGGGS)}

Figure 1. Construction of 528scFv-TRAIL expression vector. Heavy and light chain region genes of 528 are designated as $528 \mathrm{VH}$ and $528 \mathrm{VL}$ respectively. His-tag, a sequence encoding six $\mathrm{N}$-terminal histidine residues. Peptide linker, a triple repeat of four glycine and one serine residues.

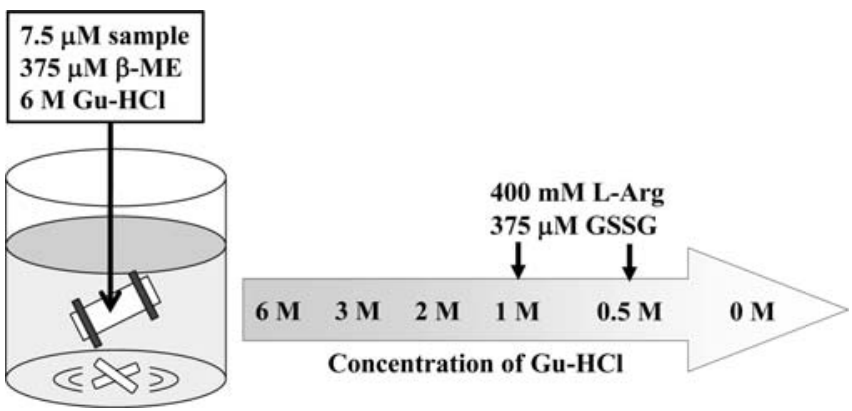

Figure 2. Procedure for refolding of E. coli-expressed recombinant $528 \mathrm{scFv}$ TRAIL. The buffer solution during refolding is either PBS or $50 \mathrm{mM}$ Tris- $\mathrm{HCl}, 200 \mathrm{mM} \mathrm{NaCl}, 1 \mathrm{mM}$ EDTA $\left(\mathrm{pH} 8.0,4^{\circ} \mathrm{C}\right)$. Each dialysis step lasts 6-12 h. $\mathrm{B}$-ME, $\mathrm{B}$-mercaptoethanol; $\mathrm{Gu}-\mathrm{HCl}$, guanidinium hydrochloride; GSSH, oxidized form of glutathione; L-arg, L-arginine.

In vitro growth inhibition assay. In vitro growth inhibition of TFK-1 cells (a human bile duct carcinoma line) was assayed with a 3-(4,5-dimethylthiazole-2-yl)-5-(3-carboxymethoxyphenyl)-2-(4-sulphophenyl)-2H-tetrazolium inner salt (MTS) assay kit (CellTiter 96 AQueous Non-Radioactive Cell Proliferation assay; Promega, Madison, WI, USA). Cell suspensions (5000 cells in $100 \mu 1$ of culture medium) were plated in 96-well, flat-bottomed plates (Costar, Cambridge, MA, USA), and the plated cells were cultured overnight to allow them to adhere to the well. After removal of the culture medium by aspiration, increasing concentrations of the recombinant fusion proteins, each in $100 \mu 1$ medium, were added to each well. After incubation of the cells for $48 \mathrm{~h}$ at $37^{\circ} \mathrm{C}$, each well was washed with PBS three times, and then $95 \mu 1$ of culture medium containing $5 \mu 1$ of a fresh mixture of MTS-phenazine methosulfate solution (Promega) was added to each well. The plates were incubated for $1 \mathrm{~h}$ at $37^{\circ} \mathrm{C}$ and then read on a microplate reader (model 3550; Bio-Rad, Hercules, CA, USA) at a wavelength of $490 \mathrm{~nm}$. Growth inhibition of target cells was calculated according to the following equation: percentage growth inhibition of target cells $=[1-(\mathrm{A} 490$ of experiment-A490 of background $) /(\mathrm{A} 490$ of control-A490 of background)] x 100 (31).

\section{Results}

Expression of 528scFv-TRAIL in E. coli. The gene encoding $528 \mathrm{scFv}$-TRAIL was inserted into the pUT vector as explained

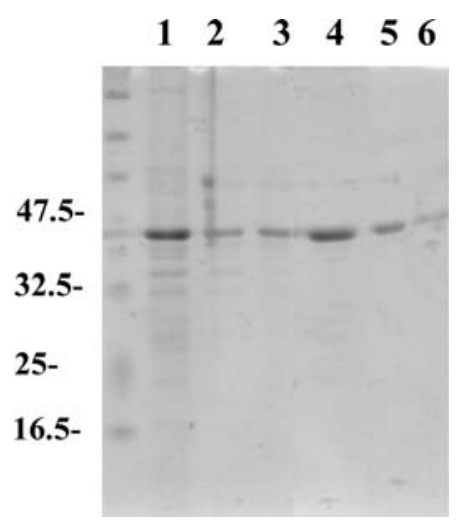

Figure 3. SDS-PAGE of fractions separated by immobilized metal affinity chromatography (IMAC) under denaturing conditions. Molecular mass markers (in kilodaltons) are shown on the left. Lane 1, total proteins in the insoluble fraction; lane 2, flow-through fraction; lane 3, wash fraction; lanes 4-6, 50, 150 and $500 \mathrm{mM}$ imidazole elution fractions.

previously. 528scFv-TRAIL recombinant fusion protein was then produced using E. coli strain BL21 (DE3) harboring the plasmid pUT-528scFv-TRAIL. The expressed fusion protein primarily existed in the intracellular fraction as inclusion bodies. As shown in Fig. 3, SDS-PAGE analysis revealed that target-size fusion protein could be retrieved with high purity from all sequential elution fractions flowing through the immobilized metal-affinity column (IMAC) under denaturing conditions. The total yield of $\mathrm{scFv}$ fusion protein was $21.4 \mathrm{mg}$ per one liter of bacterial culture.

Refolding and determination of molecular structure. To obtain soluble, functional recombinant fusion protein we optimized the refolding system previously reported by Tsumoto et al (30). We applied three parallel approaches depending on the dialysis buffer employed and whether or not adjustments of redox conditions, via treatment with thiol reagents, were performed. The recombinant protein eluted from the affinity column was diluted with $6 \mathrm{M} \mathrm{Gu-HCL/PBS}$. This denatured, purified and reduced fusion protein was then renatured by dialysis with $\mathrm{Gu}-\mathrm{HCl}$ at sequentially decreased concentrations as described in Materials and methods. Gel filtration chromatography of the refolded 528scFv-TRAIL (refolding process II) revealed a major peak corresponding to the estimated molecular weight of the monomeric form of 528scFv-TRAIL (Fig. 4A). A much lesser fraction of 528scFv-TRAIL spontaneously adopted a dimeric form yielding a smaller peak (Fig. 4A). SDS PAGE of the eluted monomeric fraction is shown in Fig. 4B.

Binding properties of $528 s c F v$-TRAIL. Binding of refolded $528 \mathrm{scFv}-\mathrm{TRAIL}$ to the targeted antigens was confirmed by flow cytometry (Fig. 5). 528scFv-TRAIL bound with the EGFR-negative, DR5-positive Jurkat cells in a manner almost identical to that of commercial recombinant TRAIL. This specific reactivity was markedly enhanced with the EGFRpositive, DR5-positive TFK-1 cells indicating a strong cumulative effect endowed by the bispecific conformation of 528scFv-TRAIL on its overall binding affinity to target antigens. 
$\mathbf{A}$

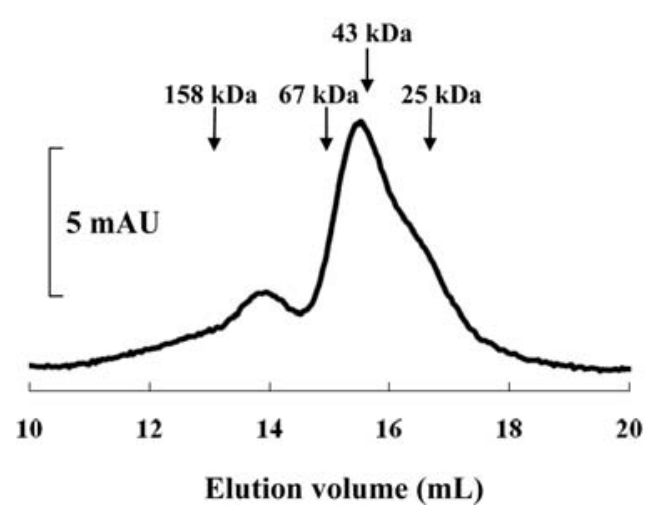

Figure 4. Gel filtration of 528scFv-TRAIL (refolding process II). (A) Chromatograph of gel filtration. Refolded 528scFv-TRAIL was subjected to gel filtration on Hiload Superdex 200-pg column (10/300). The column was pre-equilibrated with PBS, and $250 \mu 1$ of refolded $528 \mathrm{scFv}$-TRAIL was applied at a flow rate of $0.5 \mathrm{ml} / \mathrm{min}$. (B) SDS-PAGE of the eluted monomeric fraction.

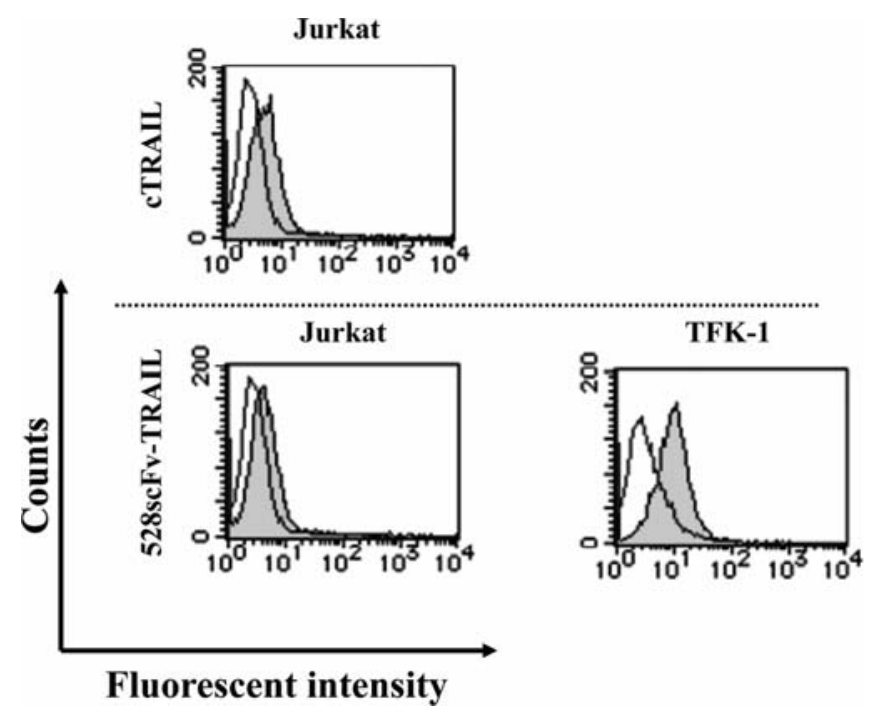

Figure 5. Flow cytometric analysis of reactivity of constructed $528 \mathrm{scFv}$-TRAIL (refolding process I) with Jurkat and TFK-1 cells. Cells were incubated with PBS as a negative control (open areas) and with commercial recombinant TRAIL (cTRAIL) as a positive control. Cells were incubated with cTRAIL or $528 \mathrm{scFv}$-TRAIL, followed by incubation with anti-TRAIL rabbit polyclonal IgG and then stained with an FITC-conjugated anti-rabbit IgG (shaded areas).

Tumoricidal activity of $528 s c F v$-TRAIL. We evaluated the anti-tumor effect of $528 \mathrm{scFv}$-TRAIL, refolded under each of the three refolding processes mentioned in Materials and methods, against the human bile duct carcinoma TFK-1 cell line. 528scFv-TRAIL (refolding process I) showed stronger tumoricidal activity when compared to its parental antiEGFR mono-specific 528scFv (Fig. 6A). This enhancement in cytotoxicity over its parental form is ascribed to summation of the apoptosis-inducing effect exerted by the TRAIL moiety in 528scFv-TRAIL. Under similar redox conditions, alteration of the refolding buffering system in refolding
A

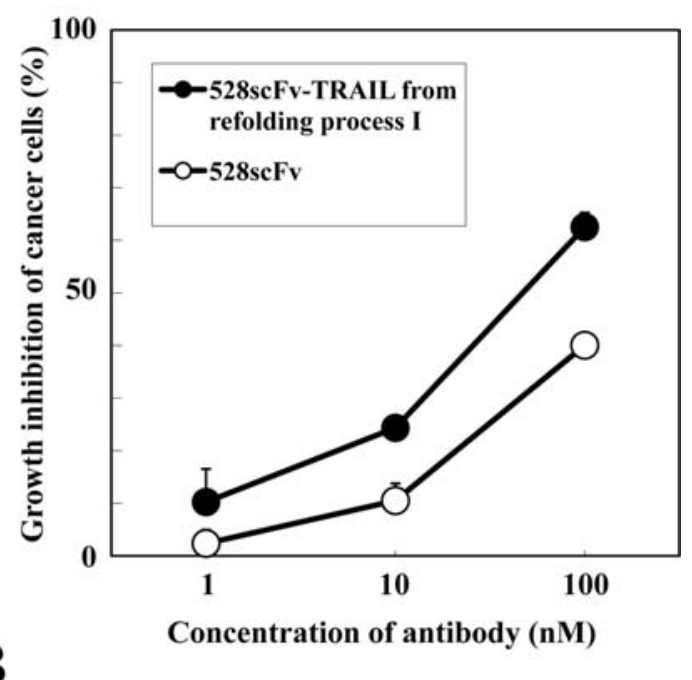

B

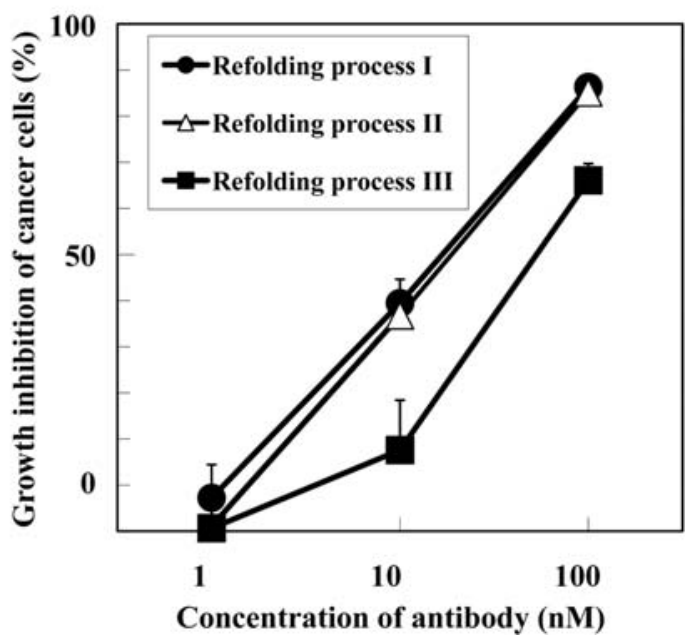

Figure 6. Growth inhibition assay of human bile duct carcinoma cell line TFK-1. Growth inhibition indices were determined by a 48-h MTS assay. (A) Cells were incubated with increasing concentrations of $528 \mathrm{scFv}$-TRAIL (refolding process I) or parental $528 \mathrm{scFv}$. (B) Cells were incubated with increasing concentrations of $528 \mathrm{scFv}$-TRAIL prepared by refolding process I, II or III. Data are mean values from at least triplicate determinations.

processes I and II did not have any significant effect on the overall recovery of biological activity. On the other hand, $528 \mathrm{scFv}$-TRAIL prepared by refolding process III, in which treatment with neither $\beta$-ME nor oxidized glutathione was performed, did show a small, but statistically significant, drop in anti-tumor activity (Fig. 6B).

\section{Discussion}

In this study, we describe an immunotherapeutic approach in which EGFR-signaling inhibition is combined with targetcell restricted apoptosis induction using the novel fusion protein $528 \mathrm{scFv}-\mathrm{TRAIL}$. We also show that recombinant $528 \mathrm{scFv}$-TRAIL, retaining competitive binding properties and potent anti-tumor activity, can be obtained by in vitro refolding under systematically constructed conditions. This modified refolding scheme is based on a previously reported 
refolding system developed in our laboratory (30) that allows the recovery of functional recombinant proteins from insoluble fractions of $E$. coli cultures in a highly efficient cost-benefit manner.

528scFv-TRAIL showed an enhanced cumulative binding affinity to the EGFR-positive, DR5-positive TFK-1 cells. The affinity of 528scFv for EGFR has been thoroughly investigated and is well established (32). On the other hand, given the monomeric structure of 528scFv-TRAIL, binding of its TRAIL moiety to DR5 receptor, however, should be interpreted in view of the incompletely characterized complexity of TRAIL receptor biology. Several groups have found experimental evidence that TRAIL receptors do not only exist in a homotrimeric form but can also form heterodimeric complexes $(12,33)$. Other reports have demonstrated strong cytotoxic activity of monomeric recombinant TRAIL refolded in vitro (34-36). Together, these reports offer the ground to explain the robust biological activity of 528scFv-TRAIL despite the fact that it existed in a predominantly monomeric form, and not as homotrimers, as was shown by gel chromatography.

Delicate control of disulfide bond formation is a crucial factor in the refolding of insoluble antibody variable fragments and a major problem with refolding is the formation of incorrect inter- and intra-molecular disulfide bridges $(37,38)$. Indeed, artificial control of the redox conditions was found to be the most effective means for optimizing the conditions for proper disulfide bond formation (30). Previous studies further suggest that the correct formation of disulfide bonds at the appropriate refolding stage may be critical for obtaining sufficient yield as well as for the efficient recovery of biological activity of the refolded recombinant protein. Pretreatment with a powerful reducing thiol reagent, such as B-ME, allows for the initial disruption of incorrect disulfide bonds, whereas adding an oxidizing thiol reagent, such as glutathione in its oxidized form, to the refolding buffer has been reported to result in the restoration of correct disulfide bonding (39). With this in mind, we kept a steady control of the concentrations of redox reagents added to the refolding system, combined with the stepwise removal of $\mathrm{Gu}-\mathrm{HCl}$. We evaluated the effects of these controlled redox conditions, as well as any potential cross-talk between redox conditions and different buffers used in dialysis, particularly on the recovery of biological activity. In our study, we found that under similar redox conditions, altering the buffering system did not result in any significant change in biological activity. However, $528 \mathrm{scFv}$-TRAIL refolded by the refolding process III, in which neither B-ME nor oxidized glutathione was added, did show a small drop in biological activity compared to refolding processes I and II in which both thiol reagents were involved. These results are in line with previous reports and further emphasize the crucial role of optimized redox conditions for recovering the biological activity of denatured recombinant proteins.

In conclusion, we managed to establish an affordable cost-benefit, time-efficient approach for the production of a bispecific recombinant fusion protein, capable of executing target cell-restricted, TRAIL-mediated apoptosis in EGFR positive tumor cells. We further claim that the refolding strategies described in this study should be applicable, with minor adjustments, to the refolding of various single-chain
Fv fragments and recombinant proteins expressed in inclusion bodies from bacterial cultures.

\section{Acknowledgements}

This work was supported by a grant-in-aid for scientific research from the Japan Society for the Promotion of Science.

\section{References}

1. Weisser NE and Hall JC: Applications of single-chain variable fragment antibodies in therapeutics and diagnostics. Biotechnol Adv 27: 502-520, 2009.

2. Walczak H, Miller RE, Ariail K, Gliniak B, Griffith TS, Kubin M, Chin W, Jones J, Woodward A, Le T, Smith C, Smolak P, Goodwin RG, Rauch CT, Schuh JC and Lynch DH: Tumoricidal activity of tumor necrosis factor-related apoptosis-inducing ligand in vivo. Nat Med 5: 157-163, 1999.

3. Pitti RM, Marsters SA, Ruppert S, Donahue CJ, Moore A and Ashkenazi A: Induction of apoptosis by Apo-2 ligand, a new member of the tumor necrosis factor cytokine family. J Biol Chem 271: 12687-12690, 1996.

4. Wiley SR, Schooley K, Smolak PJ, Din WS, Huang CP, Nicholl JK, Sutherland GR, Smith TD, Rauch C and Smith CA: Identification and characterization of a new member of the TNF family that induces apoptosis. Immunity 3: 673-682, 1995.

5. Pan G, Ni J, Wei YF, Yu G, Gentz R and Dixit VM: An antagonist decoy receptor and a death domain-containing receptor for TRAIL. Science 277: 815-818, 1997.

6. Sheridan JP, Marsters SA, Pitti RM, Gurney A, Skubatch M, Baldwin D, Ramakrishnan L, Gray CL, Baker K, Wood WI, Goddard AD, Godowski P and Ashkenazi A: Control of TRAIL-induced apoptosis by a family of signaling and decoy receptors. Science 277: 818-821, 1997.

7. Wu GS, Burns TF, McDonald ER III, Jiang W, Meng R, Krantz ID, Kao G, Gan DD, Zhou JY, Muschel R, Hamilton SR, Spinner NB, Markowitz S, Wu G and el-Deiry WS: KILLER/DR5 is a DNA damage-inducible p53-regulated death receptor gene. Nat Genet 17: 141-143, 1997.

8. Lahm A, Paradisi A, Green DR and Melino G: Death fold domain interaction in apoptosis. Cell Death Differ 10: 10-12, 2003.

9. Mongkolsapaya J, Grimes JM, Chen N, Xu XN, Stuart DI, Jones EY and Screaton GR: Structure of the TRAIL-DR5 complex reveals mechanisms conferring specificity in apoptotic initiation. Nat Struct Biol 6: 1048-1053, 1999.

10. Kischkel FC, Hellbardt S, Behrmann I, Germer M, Pawlita M, Krammer PH and Peter ME: Cytotoxicity-dependent APO-1 (Fas/CD95)-associated proteins form a death-inducing signaling complex (DISC) with the receptor. EMBO J 14: 5579-5588, 1995.

11. Sprick MR, Weigand MA, Rieser E, Rauch CT, Juo P, Blenis J, Krammer PH and Walczak H: FADD/MORT1 and caspase-8 are recruited to TRAIL receptors 1 and 2 and are essential for apoptosis mediated by TRAIL receptor 2. Immunity 12: 599-609, 2000.

12. Kischkel FC, Lawrence DA, Chuntharapai A, Schow P, Kim KJ and Ashkenazi A: Apo2L/TRAIL-dependent recruitment of endogenous FADD and caspase- 8 to death receptors 4 and 5 . Immunity 12: 611-620, 2000.

13. Stennicke HR, Jurgensmeier JM, Shin H, Deveraux Q, Wolf BB, Yang X, Zhou Q, Ellerby HM, Ellerby LM, Bredesen D, Green DR, Reed JC, Froelich CJ and Salvesen GS: Pro-caspase-3 is a major physiologic target of caspase-8. J Biol Chem 273: 27084-27090, 1998.

14. Wong AJ, Ruppert JM, Bigner SH, Grzeschik CH, Humphrey PA, Bigner DS and Vogelstein B: Structural alterations of the epidermal growth factor receptor gene in human gliomas. Proc Natl Acad Sci USA 89: 2965-2969, 1992.

15. Fischer-Colbrie J, Witt A, Heinzl H, Speiser P, Czerwenka K, Sevelda $\mathrm{P}$ and Zeillinger R: EGFR and steroid receptors in ovarian carcinoma: comparison with prognostic parameters and outcome of patients. Anticancer Res 17: 613-619, 1997.

16. Lynch TJ, Bell DW, Sordella R, Gurubhagavatula S, Okimoto RA, Brannigan BW, Harris PL, Haserlat SM, Supko JG, Haluska FG, Louis DN, Christiani DC, Settleman J and Haber DA: Activating mutations in the epidermal growth factor receptor underlying responsiveness of non-small-cell lung cancer to gefitinib. N Engl J Med 350: 2129-2139, 2004. 
17. Nonomura A, Ohta G, Nakanuma Y, Izumi R, Mizukami Y, Matsubara F, Hayashi M, Watanabe K and Takayanagi N: Simultaneous detection of epidermal growth factor receptor (EGF-R), epidermal growth factor (EGF), and ras p21 in cholangiocarcinoma by an immunocytochemical method. Liver 8: 157-166, 1988.

18. Salomon DS, Brandt R, Ciardiello F and Normanno N: Epidermal growth-factor-related peptides and their receptors in human malignancies. Crit Rev Oncol Hematol 19: 183-232, 1995.

19. De Jong JS, van Diest PJ, van der Valk P and Baak JP: Expression of growth factors, growth-inhibiting factors, and their receptors in invasive breast cancer. II: correlations with proliferation and angiogenesis. J Pathol 184: 53-57, 1998.

20. Gibson S, Tu S, Oyer R, Anderson SM and Johnson GL: Epidermal growth factor protects epithelial cells against Fasinduced apoptosis. Requirement for activation. J Biol Chem 274: 17612-17618, 1999.

21. Giordano A, Rustum YM and Wenner CE: Cell cycle: molecular targets for diagnosis and therapy-tumor suppressor genes and cell cycle progression in cancer. J Cell Biochem 70: 1-7, 1998.

22. Kerbel RS, Viloria-Petit A, Okada F and Rak J: Establishing a link between oncogenes and tumor angiogenesis. Mol Med 4: 286-295, 1998

23. Turner T, Chen P, Goodly LJ and Wells A: EGF-receptor signaling enhances in vivo invasiveness of DU-145 human prostate carcinoma cells. Clin Exp Metastasis 14: 409-418, 1996.

24. Verbeek BS, Adriaansen-Slot SS, Vroom TM, Beckers T and Rijksen G: Overexpression of EGFR and c-erbB2 causes enhanced cell migration in human breast-cancer cells and NIH3T3 fibroblasts. FEBS Lett 425: 145-150, 1998

25. Wells A: Tumor invasion: role of growth-factor-induced cell motility. Adv Cancer Res 78: 31-101, 2000.

26. Kawamoto T, Sato JD, Le A, Polikoff J, Sato GH and Mendelsohn J: Growth stimulation of A431 cells by epidermal growth factor: identification of high-affinity receptors for epidermal growth factor by an anti-receptor monoclonal antibody. Proc Natl Acad Sci USA 80: 1337-1341, 1983.

27. Hayashi H, Asano R, Tsumoto K, Katayose Y, Suzuki M, Unno M, Kodama H, Takemura S, Yoshida H, Makabe K, Imai K, Matsuno S, Kumagai I and Kudo T: A highly effective and stable bispecific diabody for cancer immunotherapy: cure of xenografted tumors by bispecific diabody and T-LAK cells Cancer Immunol Immunother 53: 497-509, 2004.

28. Krebber A, Bornhauser S, Burmester J, Honegger A, Willuda J, Bosshard HR and Pluckthun A: Reliable cloning of functional antibody variable domains from hybridomas and spleen cell repertoires employing a reengineered phage display system. J Immunol Methods 201: 35-55, 1997.
29. Hymowitz S, O'Connell M, Ultsch M, Hurst A, Totpal K, Ashkenazi A, De Vos A and Kelly R: A unique zinc-binding site revealed by a high-resolution $\mathrm{X}$-ray structure of homotrimeric Apo2L/TRAIL. Biochemistry 39: 633-640, 2000.

30. Tsumoto K, Shinoki K, Kondo H, Uchikawa M, Juji T and Kumagai I: Highly efficient recovery of functional singlechain $\mathrm{Fv}$ fragments from inclusion bodies overexpressed in Escherichia coli by controlled introduction of oxidizing reagent: application to a human single-chain Fv fragment. J Immunol Methods 219: 119-129, 1998

31. Asano R, Watanabe Y, Kawaguchi H, Fukazawa H, Nakanishi T, Umetsu M, Hayashi H, Katayose $\mathrm{Y}$, Unno M, Kudo T and Kumagai I: Highly effective recombinant format of a humanized IgG-like bispecific antibody for cancer immunotherapy with retargeting of lymphocytes to tumor cells. J Biol Chem 282: 27659-27665, 2007.

32. Makabe K, Nakanishi T, Tsumoto K, Tanaka Y, Kondo H, Umetsu M, Sone Y, Asano R and Kumagai I: Thermodynamic consequences of mutations in vernier zone residues of a humanized anti-human epidermal growth factor receptor murine antibody, 528. J Biol Chem 283: 1156-1166, 2008.

33. Clancy L, Mruk K, Archer K, Woelfel M, Mongkolsapaya J, Screaton G, Lenardo M and Chan F: Preligand assembly domain-mediated ligand-independent association between TRAIL receptor 4 (TR4) and TR2 regulates TRAIL-induced apoptosis6. Proc Natl Acad Sci USA 50: 18099-18104, 2005.

34. Shen YL, Xia XX, Zhang Y, Liu JW, Wei DZ and Yang SL: Refolding and purification of Apo2L/TRAIL produced as inclusion bodies in high-cell-density cultures of recombinant Escherichia coli. Biotechnol Lett 25: 2097-2101, 2003.

35. Lin Z, Lei $\mathrm{H}$ and Cao P: Expression, purification, and in vitro refolding of soluble tumor necrosis factor-related apoptosisinducing ligand (TRAIL). Protein Expr Purif 51: 276-282, 2007.

36. Wang D and Shi L: High-level expression, purification, and in vitro refolding of soluble tumor necrosis factor-related apoptosis-inducing ligand (TRAIL). Appl Biochem Biotechnol 157: 1-9, 2009.

37. Saxena VP and Wetlaufer DB: Formation of three-dimensional structure in proteins. I. Rapid non-enzymic reactivation of reduced lysozyme. Biochemistry 25: 5015-5023, 1970.

38. Jaenicke R and Rudolph R: Folding proteins. In: Protein Structure, A Practical Approach. Creighton TE (ed.) IRL Press, Oxford, pp191-223, 1989.

39. Goto $\mathrm{Y}$ and Hamaguchi K: The role of the intrachain disulfide bond in the conformation and stability of the constant fragment of the immunoglobulin light chain. J Biochem 86: 1433-1441, 1979. 